\title{
Study on the Cultivation Paths of Innovative and Entrepreneurship Ability of College Students from the Perspective of Managing Education by Law
}

\author{
Yuzhong Sun \\ Chongqing City Management College, Chongqing 401331, China.
}

Keywords: Managing education by law, innovation and entrepreneurship of college students, cultivation paths.

\begin{abstract}
Under the background of" public entrepreneurship and innovation”, the cultivation of innovation and entrepreneurship ability of college education is a critical important content. The cultivation of innovation and entrepreneurship ability of college education students needs to be carried out in the perspective of managing education by law. Combing the national innovation and entrepreneurship education laws and policies, it is very necessary to build a "five full" innovation and entrepreneurial ability training path. "Five full" means "full true environment, full process, full participation, fully all students and full guidance". And then, according to the law of innovation and entrepreneurship education, perfect the specific practice content of the "five full" innovation and entrepreneurship ability cultivation path.
\end{abstract}

\section{Introduction}

The main goal of higher vocational education is to cultivate high-quality technical and technical talents who serve local social and economic development. Compared with ordinary undergraduate education, we should pay more attention to cultivating college students' lifelong learning concept, focus on improving students' practical ability, creativity and employability and entrepreneurial ability. It is an important measure for vocational colleges to deepen the reform of higher vocational education, cultivate students' innovative spirit and practical ability by actively carrying out innovation and entrepreneurship education, encouraging students to innovate and start a business. It is also an important measure to realize the employment of entrepreneurship and promote the full employment of graduates. Therefore, innovation and entrepreneurship education is an important part of quality education. The same as the quality of education, innovation and entrepreneurship education needs to follow the laws of managing education by law and follow the principles of education, Therefore, innovation and entrepreneurship education and consciousness and practice of innovation and entrepreneurship all need to be carried out within the scope of the rule of law.

The legal and policy origins of cultivating innovation and entrepreneurship ability of college students

Managing education by law refers to the management and development of educational undertakings in accordance with the relevant education laws and regulations of the State and other laws and regulations relating to education. Managing education by law needs to incorporate the contents, methods and means of education according to rule of law. That means to find clear rules in the existing law and take them as guide in the education. It is the same to innovation and entrepreneurship education. Western countries realize the standardization, institutionalization, rule of law of college students' innovation and entrepreneurship mainly through the comprehensive legislation, special legislation, decentralized legislation, mixed legislation and other specialized laws and regulations. During this education, the government plays the leading role. China's current 
provisions for innovation and entrepreneurship education has not yet risen to the legal level, but more reflected in the policy documents of State Council, ministries and local governments. Although these policy documents do not belong to the laws, administrative regulations, rules and regulations, and do not have legal effect, but these non-legislative documents have universal binding in its jurisdiction. It is the executive authorities to implement the law, and they are important basis and means for administration. The contents of them are the advocacy, refinement and implementation to the laws and regulations and regulations. When the conditions are ripe, they will be included in the scope of legislation according to the legal process, so these policy provisions can also be used as legal origin of managing education by law of innovation and entrepreneurship education.

\section{The "Five full" form construction of managing education by law of cultivating innovation and entrepreneurship ability of college students}

Innovation and entrepreneurship education is a complex system of engineering, not just a course, and it will be not only related to the entire educational philosophy, personnel training objectives, personnel training programs, teaching teachers, teaching content, teaching mode, campus culture, but also related to the education management system, supporting policies and even social support. According to the content of innovation and entrepreneurship education in higher vocational education, we can summarize it into five aspects, "Five full" innovation and entrepreneurship ability cultivating path model. That means vocational innovation and entrepreneurship education needs the following paths to achieve innovative entrepreneurial education goals: "full true environment, full process, full participation, fully all students and full guidance”. "Full true environment" means to create real innovative business environment for the college students, so that students get the true innovation and entrepreneurship experience in the real environment and then exercise ability. "Full process" means the innovation and entrepreneurship education will be taught throughout the entire process of vocational education, rather than as a stage of the task. "Full participation" means during the education all the various educational subjects will be mobilized all together to play a role, such as school full-time teachers, the employment guidance teachers, public course teachers. They all required participating in the innovation and entrepreneurship education. The school should also let industry experts play roles in the student internship guidance, running business performance and working as an industry mentor and so on. Fully all students " means the innovation of entrepreneurship education is for all students, rather than just for individual students, because innovation and entrepreneurship education is not to require all students to start businesses, but to train all students to have innovative entrepreneurial awareness and ability. To carry out this basic principle is to integrate the innovation and entrepreneurship education into the main channel of teaching, through the whole process of talent training in colleges, focusing on the extensive and universal innovation and entrepreneurship education, so that each student can benefit. "1] "Full guidance" means that the college needs to supply specific guidance of all aspects of innovation and entrepreneurship to the students, rather than simply indoctrination theory. If students want to run a business, they need to be guided from the starting point to the end, such as entrepreneurial thinking, entrepreneurial action, entrepreneurial effectiveness and other aspects to be guided.

\section{Supporting policies for the "five full" innovation and entrepreneurship ability cultivating paths}

At present, the policy documents related to the content of self-entrepreneurship of college students are mostly controlled by the government departments at all levels, and they are mainly based on administrative means as the basic characteristics of the operation control mode. ${ }^{[2]}$ Since 2010 , the state and local governments have introduced more than 20 innovative business documents and corresponding supporting measures. In 2010, the Ministry of Education promulgated the "Opinions on Promoting the Innovation and Entrepreneurship Education of Higher Education and the Work of Self-Entrepreneurship in Colleges and Universities”. It required colleges and universities to carry out 
innovation and entrepreneurship education. General Secretary Xi Jinping at the Central Economic Work Conference in 2014 stressed "to create a favorable public entrepreneurship, market innovation and innovation policy system environment”." On September 10, 2014, Premier Li Keqiang in the opening ceremony of the Summer Davos Forum pointed out that the country needs to form the new situation of" everyone innovation" and "people innovation”. February 12, 2015, General Secretary Xi Jinping pointed out that the country needs to "encourage all people innovation, all people entrepreneurship" at the CPC Central Committee Political Bureau meeting. In 2015, Premier Li Keqiang once again mentioned that "Only the hundreds of millions of people's intelligence be mobilized, can we be able to usher in a new wave of innovation". On March 11, 2015 the State Council issued the "Suggestions on the development of public Creative space to promote public innovation and entrepreneurship guidance”. June 16, 2015, the State Council issued "Suggestions on the policies of promoting public innovation and entrepreneurship" .These documents provide supporting legal policy for the "five full” innovation and entrepreneurial ability training path of "full true environment, full process, full participation, fully all students and full guidance”. These policies are mainly reflected in the following aspects.

In the innovation and entrepreneurship education "full true environment" area. "Suggestions on the policies of promoting public innovation and entrepreneurship" provides that "accelerate the development of business incubation services. Vigorously develop innovative workshops, garage coffee new incubator, and construct bigger and stronger public space, perfect business incubation service." Encourage scientific and technical personnel and college students to start businesses. "The integration of national and provincial college graduates employment venture fund for college students to provide places, public services and financial support, to promote the employment of entrepreneurship." "Suggestions on the development of public Creative space to promote public innovation and entrepreneurship guidance" provides "to speed up the construction of a total space to promote the creation of space. Innovative workshops and other new incubation model ... ... to play a policy integration and synergies, to achieve innovation and entrepreneurship, line and line combination, incubation and investment combined for the majority of innovative entrepreneurs to provide a good work space, cyberspace , Social space and resource sharing space.” These regulations for innovation and entrepreneurship education provide endowed dimensions obligations for colleges and social entities to provide full real practice environment.

In the innovation and entrepreneurship education "full process" area. "Suggestions on the policies of promoting public innovation and entrepreneurship" provides "to promote the implementation of college students entrepreneurship plan to encourage colleges and universities to develop innovative entrepreneurship education courses". In addition, as early as 2010, the Ministry of Education in the " notice of doing a good job in 2010 college graduates employment" put forward the policy of treading entrepreneurship education curriculum and innovation and entrepreneurship as an important part of the industry guidance course. "The views of State Council on the deepening of the reform of innovation and entrepreneurship education in the implementation" provides that "improve the national, local and tertiary innovation and entrepreneurship training system, in-depth implementation of college students innovation and entrepreneurship training program , to expand coverage, and promote the transformation of the project.” These provisions reflect the concept of integrating innovation and entrepreneurship education throughout the whole college education process. Innovation and entrepreneurship education should be the quality education for all students. Its purpose is to lay a solid foundation for student's lifelong sustainable development. $\square$

In the innovation and entrepreneurship education "full participation" area. The State Council guidance suggestions on the accelerating the construction of public entrepreneurship innovation support platform" provides the government actively promotes the public support, "to promote colleges and universities and research institutes to small Micro-enterprises and entrepreneurs to open research facilities ", "to encourage industry associations, industry alliances and other industry organizations and third-party service agencies to strengthen the small micro-enterprises and entrepreneurs support. "The government "encourages qualified enterprises to legally initiate or participate in the establishment of public welfare venture funds, entrepreneurship 
training and guidance, corporate social responsibility." These provisions reflect that the innovation of entrepreneurship education is not only the responsibility of higher vocational colleges, but also he responsibility of the government, enterprises and industries.

In the innovation and entrepreneurship education "fully all students" area. the General Office of the State Council implementation opinions of deepening of the reform of entrepreneurship education reform in colleges" provides that by 2020 the colleges needs to establish a sound innovation and entrepreneurship education system of classroom teaching, self-learning, practice combination, guidance and help and culture leading. The quality of personnel training has improved significantly, the students' innovative spirit, entrepreneurial awareness and innovative entrepreneurial ability have been significantly enhanced, and students who have been engaged in entrepreneurial practice have increased significantly. Innovation and entrepreneurship education is for all students, rather than individual or a class of students.

In the innovation and entrepreneurship education "full guidance" area. The basic goal of entrepreneurship education is to cultivate students' overall entrepreneurship quality, that is, the quality of entrepreneurship. [3]“"The General Office of the State Council implementation opinions of deepening of the reform of entrepreneurship education reform in colleges” pointed out that local and universities should attach importance to innovation and entrepreneurship education, combined with professional education closely, not out of touch with practice; rich practical platform, provide more guidance and help. Therefore, the comprehensive guidance of students' innovation and entrepreneurship is the proper meaning of all innovative educational education documents.

\section{Conclusions}

The cultivation of innovative and entrepreneurship ability of for college students needs to follow the idea of ruling by law. China's innovation and entrepreneurship education is mainly based on the provisions of the policy level. Innovation and entrepreneurship education in the entrepreneurial environment, whole process of entrepreneurship, personnel participation, participation in students, the contents of the guidance can be found in the corresponding support policies.

\section{Acknowledgements}

This paper is one of research achievements of the project of "Study on innovation and entrepreneurship model and practice of specialty of business management basing on the cooperation between colleges and companies" which is financially supported by the "Higher education teaching reform and research project of Chongqing Education Commission of 2016”. (Project Number: 163233. Leading researcher: Yuzhong Sun.)

\section{References}

[1] Z.R.Wang Zhanren: China Higher Education Study, (2015).No.7,p.75. (In Chinese)

[2] Z.J.Zhu:Development of Human Resources, (2015).No.12,p.18. (In Chinese)

[3] L.Q.Ding:China Higher Education, (2004).No.22,p.51. (In Chinese) 